JPSCR: Journal of Pharmaceutical Science and Clinical Research, 2020, 01, 22-32

DOI: 10.20961/jpscr.v5i1.32206

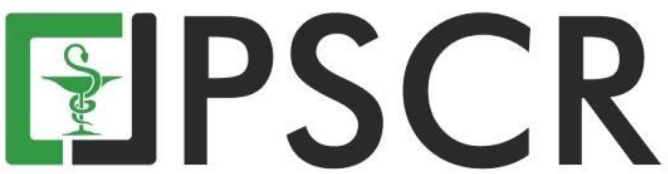

\title{
Skrining Fitokimia dan Uji Aktivitas Antibakteri Ekstrak dan Fraksi Tumbuhan Anyang-Anyang (Elaeocarpus grandiflorus J. E. Smith.) terhadap Escherichia coli
}

\author{
Ganevi R. Savitri, Bawon Triatmoko dan Ari S. Nugraha* \\ Drug Utilisation and Discovery Research Group (DUDRG), Fakultas Farmasi Universitas Jember, Jl. \\ Kalimantan I/2, Jember, Indonesia 68121 \\ *email korespondensi : arisatia@unej.ac.id
}

\begin{abstract}
Abstrak: Pada saat ini sudah banyak dilakukan penelitian terhadap khasiat antibakteri suatu tanaman. Salah satu sumber alternatif antibakteri dari bahan alam adalah tumbuhan anyanganyang. Penelitian potensi antibakteri tumbuhan anyang-anyang bertujuan untuk mengetahui nilai $\mathrm{IC}_{50}$ esktrak dan fraksi dari tumbuhan anyang-anyang (Elaeocarpus grandiflorus J. E. Smith) dalam menghambat pertumbuhan Escherichia coli (E. coli). Ekstraksi dilakukan secara maserasi dan fraksinasi secara partisi cair-cair. Uji aktivitas antibakteri yang dilakukan adalah metode mikrodilusi dengan mengacu pada protokol yang ditetapkan oleh Clinical and Laboratory Standard Institute (CLSI) M07-A9. Skrining fitokimia dilakukan dengan metode Kromatografi Lapis Tipis (KLT) untuk mengetahui golongan senyawa yang terdapat dalam ekstrak dan fraksi daun anyang-anyang. Nilai $\mathrm{IC}_{50}$ diperoleh dengan melakukan analisis probit terhadap masing-masing nilai persen penghambatan setelah pemberian 5 seri konsentrasi sampel ekstrak dan fraksi daun anyang-anyang. Kontrol positif menggunakan injeksi gentamisin $40.000 \mu \mathrm{g} / \mathrm{mL}$ dan kontrol negatif menggunakan dimetilsulfoksida (DMSO) $1 \%$. Ekstrak daun anyang-anyang memiliki IC $_{50}$ yang paling rendah yakni sebesar 360,969 $\pm 10,542$ $\mu \mathrm{g} / \mathrm{mL}$. Hasil skrining fitokimia menunjukkan sampel dan fraksi positif mengandung polifenol. Kesimpulan dari penelitian ini adalah ekstrak methanol kasar daun anyang-anyang mempunyai potensi menghambat pertumbuhan bakteri $E$. coli.
\end{abstract}

Kata kunci: Elaeocarpus grandiflorus J. E. Smith; antibakteri; mikrodilusi; Escherichia coli

\begin{abstract}
Phytochemical Screening and Antibacterial Activity of Extract and Fraction of Elaeocarpus grandiflorus J. E. Smith Against Escherichia coli. Currently research has been carried out on the antibacterial properties of a plant. An alternative way to find new antibacterial from natural ingredients is by utilizing anyang-anyang plants. This study aimed to determine the $\mathrm{IC}_{50}$ value of anyang-anyang plants (Elaeocarpus grandiflorus $\mathrm{J}$. E. Smith) in inhibiting the growth of E. coli. Anyang-anyang plants (Elaeocarpus grandiflorus J. E. Smith) were reported to have antibacterial activity against Staphylococcus aureus with MICs of 62.5 $\mu \mathrm{g} / \mathrm{mL}$. The study used extracts and fractions of anyang-anyang leaves. Extraction was carried out by maceration and fractionation using a liquid-liquid partition. The antibacterial activity test carried out was the method of microdilution regarding the protocol set by the Clinical and Laboratory Standard Institute (CLSI) M07-A9. Phytochemical screening was carried out by Thin Layer Chromatography (TLC) method to determine the group of compounds contained in the extract and fraction of anyang-anyang leaves. The $\mathrm{IC}_{50}$ value was obtained by conducting a probit analysis of each inhibitory percent value after giving 5 series
\end{abstract}


concentrations of extract samples and fractions of anyang-anyang leaves. The positive control used a gentamicin injection of $40,000 \mu \mathrm{g} / \mathrm{mL}$ and negative control using dimethylsulfoxide (DMSO) $1 \%$. Anyang-anyang leaf extract showed the lowest $\mathrm{IC}_{50}$ of $360.969 \pm 10.542 \mu \mathrm{g} / \mathrm{mL}$. The results of phytochemical screening showed samples and fractions containing polyphenols. The conclusion of this study was the extract and fraction of anyang-anyang leaves were less potent in inhibiting the growth of $E$. coli.

Keywords: Elaeocarpus grandiflorus J. E. Smith; antibacterial; microdilution; Escherichia coli

\section{Pendahuluan}

Kematian paling utama sepanjang sejarah manusia salah satunya disebabkan oleh infeksi bakteri. Berjuta orang meninggal akibat infeksi bakteri dan hal tersebut terjadi dari ribuan tahun yang lalu hingga saat ini (Walsh, 2002). Infeksi bakteri dapat diobati dengan penggunaan antibiotik. Antibiotik dapat menghentikan pertumbuhan atau mematikan bakteri penyebab infeksi. Resistensi bakteri terhadap antibiotik merupakan masalah yang dapat terjadi akibat penggunaan antibiotik yang tidak bijak dan rasional. Saat ini jumlah kasus resistensi bakteri terhadap antibiotik cukup tinggi. Penyebab resistensi antibiotik yakni akibat penggunaan antibiotik secara tidak bijak. Hal tersebut menyebabkan berbagai jenis Multidrug Resistance Organisms (MDROs) dimana bakteri tidak sensitif lagi terhadap beberapa golongan antibiotik untuk mengobati infeksi.

Bakteri gram-negatif merupakan bakteri yang banyak mengalami resistensi terhadap berbagai antibiotik (Exner dkk., 2017) hal tersebut disebabkan oleh rendahnya permeabilitas dari dinding sel bakteri gram-negatif sehingga menyebabkan antibiotik susah untuk terpenetrasi (Bérdy, 2005). Salah satu bakteri yang termasuk bakteri gram-negatif adalah bakteri Escherichia coli (E. coli). Menurut Centers for Disease Control and Prevention (CDC) (2019), penyakit yang dapat disebabkan oleh bakteri E. coli antara lain diare, infeksi saluran kemih, infeksi pernapasan, dan pneumonia.

Pemanfaatan bahan alam sebagai obat cenderung meningkat dengan adanya pola pikir back to nature (Beers, 2012) dan secara umum obat ini dinilai lebih aman karena efek samping yang dimiliki relatif lebih rendah daripada obat konvensional (Ardani dkk., 2010). Kandungan metabolit sekunder seperti alkaloid, tanin, flavonoid, terpen dan saponin pada tumbuhan memiliki efek terapi yang dapat digunakan sebagai pengobatan (Trisharyanti, 2017). Penelitian tentang tanaman obat sudah banyak dilakukan termasuk penelitian potensi antibakteri sebuah tanaman obat. Salah satu alternatif tanaman obat untuk penelitian penemuan agen antibakteri baru adalah tumbuhan anyang-anyang. 
Anyang - anyang merupakan pohon hijau dengan tinggi mencapai 25 meter yang tersebar dan banyak tumbuh di daerah beriklim tropis dan subtropics. Anyang-anyang tumbuh baik di ketinggian 1000 - $1200 \mathrm{mdpl}$, di area dengan intensitas matahari penuh. Secara tradisional ekstrak kulit dan daunnya digunakan sebagai tonik untuk meningkatkan nafsu makan, infusa kulitnya digunakan untuk demam, bisul, penyakit wanita (Rahayu dkk., 2017).

Rahman (1997) telah berhasil mengisolasi tannin, geraniin dan 3,4,5-trimetoksi geraniin dari daun anyang-anyang. Tanin, geraniin, dan 3,4,5-trimetoksi geraniin merupakan metabolit sekunder pada tanaman yang termasuk ke dalam golongan senyawa polifenol (Deaville dkk., 2010). Senyawa polifenol merupakan metabolit sekunder yang diketahui memiliki aktivitas antibakteri melalui pendenaturasian protein sel bakteri yang berakibat pada rusaknya permeabilitas dinding sel bakteri (Cushnie dan Lamb, 2005). Fraksi tak larut heksana anyang-anyang memiliki aktivitas antimikroba terhadap Staphylococcus aureus dan Candida albicans dengan MIC 62,5 $\mu \mathrm{g} / \mathrm{mL}$ dan $125 \mu \mathrm{g} / \mathrm{mL}$ (Rahman, 1997). Akan tetapi, uji aktifitas antibakteri terhadap bakteri gram negative belum dilakukan. Oleh karena itu, tujuan penelitian ini yaitu mengukur kemampuan antimikroba tanaman anyang-anyang terhadap bakteri gram negative. Dalam penelitian ini, potensi aktivitas antibakteri daun anyang-anyang diujikan terhadap satu bakteri gram negative yang cukup sering menyebabkan infeksi yaitu $E$. coli. Uji aktivitas antibakteri ekstrak dan fraksi daun anyang-anyang dilakukan dengan metode mikrodilusi untuk mengetahui nilai $\mathrm{IC}_{50}$ nya terhadap E. coli. Skrining fitokimia juga dilakukan pada penelitian ini untuk mengetahui golongan senyawa yang terkandung dalam daun anyang-anyang.

\section{Bahan dan Metode}

Bahan: Kultur bakteri E. coli ATCC 25922 yang diperoleh dari Laboratorium Mikrobiologi Fakultas Farmasi Universitas Jember, daun simplisia kering E. grandiflorus yang diperoleh dari Materia Medika, Batu, Malang. Microplate flat bottom 96 wells (Iwaki), mikropipet (Socorex dan Eppendorf), Laminar Air Flow, autoklaf (All American), microplate reader (Corona SH-1000). Bahan yang digunakan antara lain adalah metanol pro analisis (Merck), heksana (Merck), diklorometana (Merck), etil asetat (Merck), DMSO (Merck), $\mathrm{CaCl}_{2}$ dan $\mathrm{MgCl}_{2}$ (Merck), plat silika gel $60 \mathrm{~F}_{254}$ (Merck), Mueller Hinton Broth (MHB) dan Mueller Hinton Agar (MHA), injeksi gentamisin $40 \mathrm{mg} / \mathrm{mL}$.

\subsection{Preparasi sampel}

Tumbuhan yang diperoleh dari Materia Medika sudah dalam bentuk simplisia kering. Simplisia yang diperoleh selanjutnya dikecilkan ukurannya menggunakan blender. Serbuk yang diperoleh kemudian diayak dengan ayakan mesh 100. Sebanyak $100 \mathrm{~g}$ serbuk 
dimasukkan ke dalam erlenmeyer tertutup lalu ditambahkan $200 \mathrm{~mL}$ pelarut metanol pro analisis. Ekstraksi dilakukan diatas stirer selama 24 jam. Ekstrak disaring dan dikumpulkan filtratnya lalu dilakukan remaserasi selama 24 jam. Filtrat yang terkumpul dipekatkan. Proses ekstraksi menghasilkan ekstrak sebesar 2,5837 g.

\subsection{Pembuatan fraksi}

Metode yang dipilih untuk fraksinasi adalah metode partisi cair-cair secara bertingkat dengan bantuan penggojogan. 1,0988 g ekstrak kering dilarutkan dalam $90 \mathrm{~mL}$ air dan $10 \mathrm{~mL}$ metanol lalu dipartisi dengan heksana yang akan membentuk 2 fase. Fase atas diambil dan ditampung sebagai fraksi heksana. Fraksi yang diperoleh lalu disaring dan dipekatkan. Fraksinasi selanjutnya dilakukan dengan $100 \mathrm{~mL}$ diklorometana. Fase bawah diambil dan ditampung sebagai fraksi diklorometana. Setelah diperoleh fraksi diklorometana maka disaring dan dipekatkan. Fraksinasi dilanjutkan menggunakan $100 \mathrm{~mL}$ etil asetat. Fase atas diambil lalu ditampung sebagai fraksi etil asetat. Setelah diperoleh fraksi etil asetat, fraksi tersebut dipisahkan dari residu lalu dipekatkan. Fraksinasi menghasilkan fraksi heksana sebesar 0,0975 g, fraksi diklorometana sebesar 0,083 g, fraksi etil asetat sebesar 0,1051 g, dan residu sebesar 0,5219 g. Ketiga fraksi dan residu yang diperoleh kemudian diuji aktivitas antibakteri guna mengetahui fraksi yang memiliki aktivitas terbaik.

\subsection{Uji aktivitas antibakteri}

Uji aktivitas antibakteri dilakukan dengan metode mikrodilusi yang disesuaikan dengan protokol yang telah distandardisasi oleh Clinical and Laboratory Standard Institute (CLSI) M07-A9. Konsentrasi sampel yang digunakan adalah $2048 \mu \mathrm{g} / \mathrm{mL}, 1024 \mu \mathrm{g} / \mathrm{mL}, 512$ $\mu \mathrm{g} / \mathrm{mL}, 256 \mu \mathrm{g} / \mathrm{mL}, 128 \mu \mathrm{g} / \mathrm{mL}$. DMSO 1\% digunakan sebagai kontrol negatif dan kontrol positif yang digunakan adalah injeksi gentamisin $40 \mathrm{mg} / \mathrm{mL}$ yang diencerkan hingga diperoleh konsentrasi $4 \mu \mathrm{g} / \mathrm{mL}, 2 \mu \mathrm{g} / \mathrm{mL}, 1 \mu \mathrm{g} / \mathrm{mL}$, dan $0,5 \mu \mathrm{g} / \mathrm{mL}$.

\subsection{Identifikasi kandungan kimia}

Ekstrak dan fraksi daun anyang-anyang selanjutnya dilakukan penapisan kandungan metabolit sekunder alkaloid, flavonoid, polifenol, dan terpenoid. Pemeriksaan dilakukan dengan metode KLT, sampel dilarutkan ke dalam metanol lalu ditotolkan pada lempeng KLT silika $\mathrm{GF}_{254}$. Fase gerak alkaloid menggunakan metanol : etil asetat : toluen (1:2:7) dan penampak noda dragendroff. Fase gerak flavonoid menggunakan asam asetat glasial : butanol : air (1:4:5) dengan penampak noda uap ammonia. Fase gerak polifenol menggunkan kloroform : etil asetat (1:9) dengan penampak noda $\mathrm{FeCl}_{3}$. Fase gerak terpenoid menggunakan heksana : etil asetat (4:1) dengan penampak noda anisaldehid asam sulfat. 


\subsection{Analisis data}

Skrining fitokimia akan memberikan hasil berupa perubahan warna terhadap ekstrak atau fraksi yang diuji. Perubahan warna nantinya disesuaikan dnegan literatur yang ada sehingga diperoleh golongan senyawa dari masing-masing sampel.

Uji aktivitas antibakteri dengan metode mikrodilusi akan menghasilkan data absorbansi. Besarnya penghambatan bakteri dapat dihitung dengan rumus dibawah. Setelah diperoleh data tingkat penghambatan pertumbuhan bakteri (persen penghambatan) maka dilakukan analisis probit untuk memperoleh nilai $\mathrm{IC}_{50}$ (Persamaan 1).

$$
\% \text { Penghambatan }=\left(1-\frac{(A b s \cdot R-A b s S)}{(A b s . P-A b s \cdot Q)}\right) \times 100 \%
$$

Persamaan 1. Persamaan pengukuran persentase penghambatan pengujian aktivitas antibakteri (dimodifikasi oleh Quave dkk., 2008 dalam Ardani dkk., 2010). Keterangan: absorbansi (Abs), kontrol negatif (DMSO 1\% atau media + suspensi bakteri) (P), kontrol media (DMSO 1\% atau media) (Q), uji (ekstrak/fraksi/gentamisin + suspensi bakteri) (R), kontrol uji (ekstrak/fraksi/gentamisin + media) (S)

\section{Hasil dan Pembahasan}

\subsection{Skrining fitokimia}

Golongan senyawa yang terkandung dalam ekstrak dan fraksi daun anyang-anyang dapat diketahui melalui skrining fitokimia . Hasil skrining fitokimia tercantum pada Tabel 1.

Tabel 1. Hasil Skrining Fitokimia pada Ekstrak dan Fraksi Daun Anyang-Anyang Keterangan: ada (+) dan tidak ada (-).

\begin{tabular}{lcccc}
\hline \multirow{2}{*}{ Sampel } & \multicolumn{4}{c}{ Golongan Senyawa } \\
\cline { 2 - 5 } & Alkaloid & Flavonoid & Polifenol & Terpenoid \\
\hline Ekstrak & + & + & + & + \\
Fraksi heksana & - & - & + & + \\
Fraksi diklorometana & + & - & + & + \\
Fraksi etil asetat & - & - & + & - \\
Residu & - & + & + & - \\
\hline
\end{tabular}

\subsubsection{Identifikasi senyawa golongan alkaloid}

Skrining fitokimia untuk mendeteksi keberadaan golongan senyawa alkaloid menggunakan reagen dragendorff. Hasil skrining fitokimia menunjukkan bahwa ekstrak metanol dan fraksi diklorometana daun anyang-anyang mengandung golongan senyawa alkaloid yang ditunjukkan dengan adanya noda berwarna jingga sedangkan fraksi lainnya menunjukkan hasil negatif karena tidak terdapat noda berwarna jingga. Penelitian pada genus Elaeocaparpus lainnya menunjukkan bahwa pada daun Elaeocarpus sphaericus memiliki kandungan alkaloid (Singh dkk, 2000). 


\subsubsection{Identifikasi senyawa golongan flavonoid}

Skrining fitokimia senyawa golongan flavonoid menunjukkan hasil positif bila tampak noda berwarna kuning setelah diberi penampak noda uap amonia (Harborne, 1998). Hasil KLT menunjukkan ekstrak metanol dan residu daun anyang-anyang positif mengandung flavonoid sedangkan fraksi heksana, fraksi diklorometana, dan fraksi etil asetat tidak mengandung flavonoid karena tidak nampak noda berwarna kuning. Belum terdapat penelitian identifikasi golongan flavonoid pada tumbuhan anyang-anyang namun penelitian lain menunjukkan bahwa dalam genus Elaeocarpus lainnya yakni Elaeocarpus sphaericus mengandung flavonoid (Singh dkk, 2000).

\subsubsection{Identifikasi senyawa golongan polifenol}

Skrining fitokimia senyawa golongan polifenol menunjukkan hasil positif bila muncul noda berwarna hitam setelah disemprot dengan menggunakan penampak noda $\mathrm{FeCl}_{3}$ (Harborne, 1998). Noda berwarna hitam menunjukkan hasil positif. Hasil pengujian secara KLT menunjukkan bahwa ekstrak metanol, fraksi heksana, fraksi diklorometana, fraksi etil asetat, dan residu positif mengandung golongan senyawa polifenol. Berdasarkan literatur, geraniin dan 3,4,5-trimetoksi geraniin adalah senyawa golongan polifenol yang pernah diisolasi dari daun anyang-anyang (Rahman, 1997).

\subsubsection{Identifikasi senyawa golongan terpenoid}

Skrining fitokimia senyawa golongan polifenol menunjukkan hasil positif bila muncul noda berwarna merah ungu atau ungu setelah disemprot dengan penampak noda anisaldehida asam sulfat (Harborne, 1998). Pengujian secara KLT pada ekstrak metanol, fraksi heksana, dan fraksi diklorometana daun anyang-anyang menunjukkan hasil positif karena terdapat noda berwana ungu sedangkan pada fraksi etil asetat, dan residu daun anyanganyang menunjukkan hasil negatif karena tidak terdapat noda merah ungu atau ungu. Belum ada penelitian terkait identifikasi senyawa golongan terpenoid pada daun anyang-anyang namun penelitian pada genus yang sama menunjukkan bahwa Elaeocarpus floribundus mengandung terpenoid (Deivasigamani dkk., 2018).

\subsection{Uji aktivitas antibakteri}

Uji aktivitas antibakteri dilakukan pada ekstrak metanol, fraksi heksana, fraksi diklorometana, fraksi etil asetat, dan residu daun anyang-anyang terhadap bakteri E. coli. Metode uji yang digunakan adalah mikrodilusi karena dapat untuk menentukan nilai $\mathrm{IC}_{50}$. Pengujian yang dilakukan mengacu pada protokol yang telah ditentukan oleh Clinical and Laboratory Standard Institute (CLSI). Pengujian menggunakan media Cation Adjusted Mueller Hinton Broth (CAMHB). CLSI merekomendasikan media CAMHB untuk pengujian 
antibakteri sebab media Mueller-Hinton yang diproduksi oleh banyak pabrik memiliki kandungan kation $\mathrm{Ca}^{2+}$ dan $\mathrm{Mg}^{2+}$ yang bervariasi (Akpolat dkk., 2001). Jumlah kation $\mathrm{Ca}^{2+}$ dan $\mathrm{Mg}^{2+}$ yang terdapat pada media harus dihitung terlebih dahulu sebelum dilakukan penambahan kation (Barry dkk., 1992). Perbedaan jumlah kation $\mathrm{Ca}^{2+}$ dan $\mathrm{Mg}^{2+}$ yang ada pada media akan mempengaruhi hasil pengujian terutama pada metode dilusi yang digunakan untuk pengukuran kuantitatif sehingga jumlah kation perlu distandardisasi terlebih dahulu.

Ekstrak dan fraksi daun anyang-anyang dilarutkan dalam media dengan kosolven DMSO 1\%. CLSI merekomendasikan penggunaan DMSO tidak lebih dari 1\% (CLSI, 2018). Berkaitan dengan penggunaan DMSO sebagai kosolven maka DMSO digunakan sebagai kontrol negatif pada penelitian ini. Kontrol negatif digunakan untuk menguji solven yang digunakan memiliki aktivitas penghambatan bakteri atau tidak. DMSO yang digunakan pada penelitian ini menunjukkan tidak adanya penghambatan pertumbuhan bakteri yang ditunjukkan dengan nilai negatif pada persentase penghambatan DMSO yang terdapat pada Tabel 2.

Uji aktivitas antibakteri menggunakan kontrol positif gentamisin dengan seri konsentrasi $4 \mu \mathrm{g} / \mathrm{mL}, 2 \mu \mathrm{g} / \mathrm{mL}, 1 \mu \mathrm{g} / \mathrm{mL}, 0,5 \mu \mathrm{g} / \mathrm{mL}$ dan konsentrasi ekstrak metanol serta fraksi daun anyang-anyang yang digunakan adalah $2048 \mu \mathrm{g} / \mathrm{mL}, 1024 \mu \mathrm{g} / \mathrm{mL}, 512 \mu \mathrm{g} / \mathrm{mL}$, $256 \mu \mathrm{g} / \mathrm{mL}, 128 \mu \mathrm{g} / \mathrm{mL}$. Konsentrasi yang digunakan dipilih berdasarkan optimasi penelitian untuk memperoleh nilai $\mathrm{IC}_{50}$ dari sampel uji yang digunakan. Persentase penghambatan bakteri oleh kontrol positif gentamisin terdapat pada Tabel 3.

Tabel 2. Nilai persentase penghambatan pertumbuhan Escherecia coli oleh gentamisin dan dimetilsulfoksida (DMSO).

\begin{tabular}{lcll}
\hline Kontrol & $\begin{array}{c}\text { Rerata Penghambatan } \\
\text { Pertumbuhan Bakteri (\%) }\end{array}$ & $\begin{array}{c}\text { SD } \\
(\boldsymbol{\%})\end{array}$ & $\begin{array}{l}\text { CV } \\
(\boldsymbol{\%})\end{array}$ \\
\hline Gentamisin $(0,5$ & 83,919 & 1,118 & 1,332 \\
$\mu \mathrm{g} / \mathrm{mL})$ & & & \\
Gentamisin $(1 \mu \mathrm{g} / \mathrm{mL})$ & 90,678 & 0,545 & 0,601 \\
Gentamisin $(2 \mu \mathrm{g} / \mathrm{mL})$ & 95,478 & 0,309 & 0,324 \\
Gentamisin $(4 \mu \mathrm{g} / \mathrm{mL})$ & 99,362 & 0,661 & 0,666 \\
DMSO $(1 \%)$ & $-17,714$ & 1,200 & 6,775 \\
\hline
\end{tabular}

Kontrol positif digunakan sebagai evaluasi untuk mengetahui metode pengujian yang digunakan telah memberikan data yang baik. MIC gentamisin pada bakteri E.coli ATCC 25922 yang dipersyaratkan oleh CLSI sebesar $\leq 4 \mu \mathrm{g} / \mathrm{mL}$ (CLSI, 2017). Berdasarkan data persentase penghambatan diatas menunjukkan bahwa metode yang digunakan telah baik karena MIC kontrol positif gentamisin telah memenuhi persyaratan. 
Berdasarkan hasil pengujian menunjukkan bahwa ekstrak metanol, fraksi heksana, fraksi diklorometana, fraksi etil asetat, dan residu memiliki aktivitas penghambatan pertumbuhan bakteri E. coli. Aktivitas penghambatan ditentukan dengan nilai $\mathrm{IC}_{50}$ yang diperoleh melalui analisis probit dengan taraf kepercayaan 95\%. Nilai IC 50 masing-masing sampel terdapat pada Tabel 3. The Commision of The European Communities (2005) mempersyaratkan keterulangan suatu metode penelitian dengan pengujian berbasis sel tidak lebih dari $30 \%$ sehingga keterulangan metode pengujian yang dilakukan dalam penelitian ini dapat diterima.

Nilai IC $_{50}$ terendah pada penelitian ini terdapat pada ekstrak metanol yakni sebesar $360,969 \mu \mathrm{g} / \mathrm{mL}$. Nilai $\mathrm{IC}_{50}$ pada pengujian anti-infektif dapat dikatakan baik bila $\mathrm{IC}_{50}$ dibawah $100 \mu \mathrm{g} / \mathrm{mL}$ untuk ekstrak dan dibawah $25 \mu \mathrm{M}$ untuk senyawa murni (Cos dkk., 2006). Ketika ekstrak kasar mempunyai $\mathrm{IC}_{50}$ kurang dari $1024 \mu \mathrm{g} / \mathrm{mL}$ maka ekstrak bias dikatakan mempunyai potensi antibakteri yang signifikan sehingga perlu dilakukan penelitian lebih lanjut (Nugraha et al, 2019). Hasil pengujian antibakteri ekstrak dan fraksi-fraksi daun anyang-anyang tersaji pada Tabel 3.

Tabel 3. Nilai $\mathrm{IC}_{50}$ ekstrak dan fraksi daun anyang-anyang (Elaeocarpus grandiflorus J. E. Smith.) terhadap pertumbuhan bakteri Escherecia coli

\begin{tabular}{lrrr}
\hline \multicolumn{1}{c}{ Sampel } & IC $\mathbf{5 0}(\boldsymbol{\mu g} / \mathbf{m L})$ & SD $(\boldsymbol{\mu g} / \mathbf{m L})$ & CV $(\boldsymbol{\%})$ \\
\hline Ekstrak metanol & 360,969 & 10,542 & 2,921 \\
Fraksi heksana & 1700,669 & 72,295 & 4,251 \\
Fraksi diklorometana & 931,392 & 66,736 & 7,165 \\
Fraksi etil asetat & 1082,715 & 67,798 & 6,262 \\
Residu & 1205,687 & 130,771 & 10,846 \\
\hline
\end{tabular}

Sifat antibakteri dari suatu ekstrak dan fraksi dapat ditentukan oleh adanya kandungan berbagai golongan dari metabolit sekunder aktif yang potensial. Sifat antibakteri dapat berasal dari senyawa individu atau gabungan dari mekanisme kerja senyawa-senyawa yang ada (Njateng dkk., 2017). Dalam penelitian ini, nilai $\mathrm{IC}_{50}$ ekstrak methanol lebih rendah disbanding dengan fraksi-fraksi dari ekstrak metanol. Adanya sifat aditif atau sinergisme pada senyawa-senyawa antibakteri yang terkandung dalam ekstrak memungkinkan ekstrak metanol memiliki nilai $\mathrm{IC}_{50}$ yang lebih rendah atau kemungkinan juga terjadi dekomposisi selama proses fraksinasi sehingga senyawa-senyawa yang terkandung dalam fraksi menjadi rusak atau aktivitas antibakterinya menurun (Houghton dan Raman, 2011).

Berdasarkan hasil skining fitokimia menunjukkan bahwa ekstrak metanol daun anyang-anyang memiliki kandungan golongan senyawa yang paling banyak daripada fraksi heksana, fraksi diklorometana, fraksi etil asetat, dan residu. Hal tersebut sejalan dengan 
perolehan nilai $\mathrm{IC}_{50}$ dari ekstrak metanol yang lebih kecil dibanding fraksi heksana, fraksi diklorometana, fraksi etil asetat, dan residu.

Hasil skrining fitokimia menunjukkan bahwa ekstrak metanol daun anyang-anyang positif memiliki kandungan golongan senyawa alkaloid, flavonoid, terpenoid, dan polifenol. Selain itu keempat sampel menunjukkan hasil positif terhadap golongan polifenol. Golongan senyawa tersebut diketahui memiliki aktivitas antibakteri. Rahman (1997) juga berhasil mengisolasi tanin, geraniin, dan 3,4,5-trimetoksi geraniin dari daun anyang-anyang. Tanin, geraniin, dan 3,4,5-trimetoksi geraniin merupakan metabolit sekunder pada tanaman yang termasuk ke dalam golongan senyawa polifenol (Deaville dkk., 2010). Senyawa-senyawa tersebut kemungkinan turut terlibat dalam memberikan aktivitas antibakteri pada ekstrak. Senyawa tanin sendiri memiliki aktivitas antibakteri menyebabkan inaktivasi adhesin sel mikroba dan enzim, dan terggangunya transport protein pada lapisan dalam sel (Ferreira dkk., 2008) melalui pembentukan senyawa kompleks dengan enzim atau substrat (Januarti dkk., 2019). Mekanisme antibakteri senyawa polifenol dalam membunuh mikroorganisme yaitu dengan mendenaturasi protein sel yang menyebabkan terjadinya kerusakan permeabilitas dinding sel bakteri (Cushnie dan Lamb, 2005).

Penelitian Rahman (1997) menunjukkan bahwa ekstrak kloroform-metanol dan fraksi tak larut heksana daun anyang-anyang konsentrasi $1000 \mu \mathrm{g} / \mathrm{mL}$ memiliki aktivitas antimikroba terhadap bakteri gram positif Staphylococcus aureus dengan MIC 62,5 $\mu \mathrm{g} / \mathrm{mL}$. Berdasarkan uraian diatas disarankan untuk dilakukan penelitian lebih lanjut terhadap aktivitas antibakteri daun anyang-anyang terutama terhadap bakteri yang lain untuk mencari bakteri yang sensitive terhadap kandungan ekstrak daun anyng-anyang. Adanya penurunan aktivitas antibakteri dari fraksi-fraksi turunan dari ektrak methanol, maka diperlukan adanya metode yang aman untuk menghindari degradasi kandungan kimia selama proses fraksinasi.

\section{Kesimpulan}

Berdasarkan penelitian yang telah dilakukan dapat disimpulkan bahwa daun anyanganyang tidak poten dalam menghambat pertumbuhan bakteri E.coli. Ekstrak metanol memiliki nilai $\mathrm{IC}_{50}$ yang paling rendah hal tersebut kemungkinan dapat disebabkan adanya sifat sinergisme dari metabolit sekunder yang terkandung. Senyawa metabolit sekunder yang kemungkinan aktif sebagai agen antibakteri pada keempat sampel adalah polifenol.

Berdasarkan uraian diatas disarankan untuk dilakukan penelitian lebih lanjut terhadap aktivitas antibakteri daun anyang-anyang terutama terhadap bakteri lain termasuk bakteri gram positif. Isolasi kandungan senyawa diperlukan untuk mendapatak senyawa murni yang bertanggung jawab terhadap aktivitas antibakteri. 


\section{Ucapan Terimakasih}

Penulis mengucapkan terimakasih kepada Universitas Jember atas dukungan fasilitas penelitian.

\section{Deklarasi Konflik Kepentingan}

Semua penulis menyatakan tidak ada konflik kepentingan terhadap naskah ini.

\section{Daftar Pustaka}

Akpolat, N., T. Özekinci, dan S. Atmaca. (2001). Effect of mg+2 concentration in muellerhinton agar on the susceptibility of pseudomonas aeruginosa to levofloxacin. Turkish Journal of Medical Sciences, 31(6):585-586.

Ardani, M., Pratiwi, S.U.T. dan Hertiani T. (2010). Efek campuran minyak atsiri daun cengkeh dan kulit batang kayu manis sebagai antiplak gigi. Majalah Farmasi Indonesia, 3(21): 194 .

Barry, A.L., Reller, L.B., Miller, G.H., Washington, J.A., Schoenknect, F.D., Peterson, L.R., Hare, R.S., dan Knapp, C. (1992). Revision of standards for adjusting the cation content of mueller-hinton broth for testing susceptibility of pseudomonas aeruginosa to aminoglycosides. Journal of Clinical Microbiology, 30(3):585-589.

Beers, S.J. (2012). Jamu: The ancient Indonesian art of herbal healing. Tuttle Publishing. North Clarendon, USA.

Bérdy, J. (2005). Bioactive microbial metabolites. The Journal of Antibiotics, 58(1):1-26.

CDC. 2019. E. coli (Escherichia coli) | E. coli | CDC. https://www.cdc.gov/ecoli/index.html [Diakses pada 22 Juni 2019].

CLSI. (2017). M100 Performance Standards for Antimicrobial Susceptibility Testing. 3. Journal of Services Marketing.

CLSI. (2018). Clinical and laboratory standards institute. methods for dilution antimicrobial susceptibility tests for bacteria that grow aerobically. CLSI Standard M07

Cos, P., Vlietinck, A.J., Vanden-Berghe, D., dan Maes, L. (2006). Anti-infective potential of natural products: how to develop a stronger in vitro "proof-of-concept". Journal of Ethnopharmacology, 106(3):290-302.

Cushnie, T. P. T. dan Lamb, A. J. (2005). Antimicrobial activity of flavonoids. International Journal of Antimicrobial Agents, 26(5):343-356.

Deaville, E.R., Givens, D.I. dan Mueller-Harvey, I. (2010). Chestnut and mimosa tannin silages: effects in sheep differ for apparent digestibility, nitrogen utilisation and losses. Animal Feed Science and Technology, 157(3-4):129-138.

Exner, M., Bhattacharya, S., Christiansen, B., Gebel, J., Goroncy-Bermes, P., Hartemann, P., Heeg, P., Ilschner, C., Kramer, A., Larson, E., Merkens, W., Mielke, M., Oltmanns, P., Ross, B., Rotter, M., Schmithausen, R.M., Sonntag, H.G., dan Trautmann, M. (2017). Antibiotic resistance: what is so special about multidrug-resistant gram-negative bacteria? GMS Hygiene and Infection Control, 12:Doc05.

Ferreira, D., Gross, G.G., Hagerman, A.E., Kolodziej, H., dan Yoshida, T. (2008). Tannins and related polyphenols: perspectives on their chemistry, biology, ecological effects, and human health protection. Phytochemistry, 69(18):3006-3008.

Harborne, J. B. (1998). Phytochemical Methods; A Guide to Modern Techniques of Plant Analysis. Springer science and business media.

Houghton, P. J. dan Raman, A. (2011). Analysis of crude extracts, fractions and isolated compounds. Laboratory Handbook for the Fractionation of Natural Extracts. 113-138.

Januarti, I. B., Wijayanti, R., Wahyuningsih, S. dan Nisa, Z. (2019). Potensi ekstrak terpurifikasi daun sirih merah (piper crocatum ruiz \&pav) sebagai antioksidan dan antibakteri. JPSCR : Journal of Pharmaceutical Science and Clinical Research, 4(2):60. 
Njateng, G.S.S., Du, Z., Gatsing, D., Mouokeu, R.S., Liu, Y., Zang, H.X., Gu, J., Luo, X., dan Kuiate, J.-R. (2017). Antibacterial and antioxidant properties of crude extract, fractions and compounds from the stem bark of polyscias fulva hiern (araliaceae). BMC Complementary and Alternative Medicine, 17(1):99.

Nugraha, A.S., Pratoko, D.K., Damayanti, Y.D., Lestari, N.D., Laksono, T.A., Addy, H.S., Untari, L.F., Kusumawardani, B., and Wangchuk, P. (2019). Antibacterial and anticancer activities of nine lichens of Indonesian Java island. Journal of Biologically Active Products from Nature, 9(1), 39-46.

Quave, C.L., Plano, L.R.W., Pantuso, T., dan Bennett, B.C. (2008). Effects of extracts from italian medicinal plants on planktonic growth, biofilm formation and adherence of methicillin-resistant staphylococcus aureus. Journal of Ethnopharmacology, 118(3):418428.

Rahayu, E., Dewi, N., dan Bodijantoro, F. (2017). Profile of elaeocarpus grandiflorus and ziziphus mauritiana as identity plants of salatiga and tegal towns, central java province, indonesia. Journal of Physics: Conference Series, 983(1), p. 012195.

Rahman, A. (1997). Isolasi dan identifikasi senyawa antimikroba dari daun elaeocarpus grandiflorus j.e. smith. Doctoral Dissertation, Universitas Gadjah Mada.

Singh, R.K., Acharya, S.B., Bhattacharya, S.K. (2000). Pharmacological activity of Elaeocarpus sphaericus. Phytotherapy Research. 14(1):36-39.

The Commision of The European Communities. (2005). Requirements For The Determination Of Levels Of Dioxins And Dioxin-Like Pcbs In Feedingstuffs Rules. The Commision of The European Communities.

Trisharyanti, I. (2017). Skrining aktivitas antibakteri ekstrak etanol daun terhadap salmonella typhi resisten kloramfenikol. JPSCR : Journal of Pharmaceutical Science and Clinical Research, 2(2):66.

Walsh, C. T. (2002). Magic bullets, lost horizons: the rise and fall of antibiotics. Nature Medicine, 8:1

\section{(c) (1) (2)}

C 2020 by the authors. Submitted for possible open access publication under the terms and conditions of the Creative Commons Attribution-ShareAlike 4.0 International (CC BY-SA 4.0) license (https://creativecommons.org/licenses/by-sa/4.0/). 